\title{
Imagining the Middle East: the state, nationalism and regional international society
}

\section{Ayla Göl}

To cite this article: Ayla Göl (2015) Imagining the Middle East: the state, nationalism and regional international society, Global Discourse, 5:3, 379-394, DOI: 10.1080/23269995.2015.1053191

To link to this article: https://doi.org/10.1080/23269995.2015.1053191

里 Published online: 24 Jul 2015.

Submit your article to this journal 주

Џll Article views: 323

View Crossmark data \lceil

Citing articles: 2 View citing articles ๘ 


\title{
RESEARCH ARTICLE
}

\section{Imagining the Middle East: the state, nationalism and regional international society}

Ayla Gö1*

Department of International Politics, Aberystwyth University, Wales, UK

\begin{abstract}
The Middle East is commonly perceived as a zone of cultural and political differences within the global international society. Imagining the Middle East as a 'unique' region is not a new idea, but relocating this conception within the English School (ES) of International Relations (IR) is. This article challenges the perceived 'exceptionalism' of the Middle East, which claims that the European concepts of state, sovereignty and nationalism are alien to Islam, therefore preventing the emergence of a regional international society. The first part highlights the correlation between Eurocentrism in IR and the lack of interest in regional - area - studies through the critique of Orientalism and the ES. The second part moves to demonstrate why the ES is more explanatory than other IR theories in the context of the Ottoman-European relations. The third part explores the 'institutional distinctiveness' of the Middle East, disproving the notion of regional 'exceptionalism' and IR's foundational Eurocentric assumptions. This article concludes by arguing that there is a strong case for calling the Middle East a 'regional interstate society', which remains to be a litmus test of whether or not a truly global international society is possible.
\end{abstract}

Keywords: The English School of International Relations; Islam; the Islamic State; the Middle East; nationalism; the Ottoman Empire; pan-Arabism; pan-Islamism; regional international society

\section{Introduction}

The Middle East is commonly perceived as a zone of cultural and political differences in the global international society. Imagining the Middle East as a 'unique' region is not a new idea, but relocating it within the English School (ES) of International Relations (IR) is. The editors of this special issue are interested in understanding the relationship dynamics between the global international and regional international societies. This article aims to contribute towards a new research agenda, which explores whether or not there is a regional international society in the Middle East. By initiating this question within the ES, the existence of an international society at the global level is fundamentally questioned, given that the assumed lack of a Middle Eastern regional society essentially challenges the Western-global international order.

The main assumptions within this article are threefold: first is that the Middle East is an illuminating regional case study. This derives firstly from the regions' close historic relations with European powers, and secondly from the contested nature of Islam's encounter with Western values and institutions in contemporary international relations. Second, while the study of the Middle East is under-theorized and marginalized in IR, the

*Email: ayg@aber.ac.uk 
ES, in spite of its weakness and limits, allows us to interrogate the relations between regional and international levels. Third, the Middle East as a regional context offers both opportunities and challenges to this interrogation through questioning the expansion of international society to the Islamic world through the legacy of Ottoman-European affairs. The findings of this investigation have important value to add to the existing theoretical and empirical insights of ES scholars through an exploration of the relations between global international society and a 'regional interstate society' in the Middle East (Buzan and Gonzalez-Pelaez 2009, 241).

The article challenges the 'exceptionalism' of the Middle East, which claims that the European concepts of state, sovereignty and nationalism are alien to Islam, therefore preventing the emergence of a regional international society. The article first explains the correlation between Eurocentrism in IR and the lack of interest in regional - area studies despite IR's claims to be 'international'. Understanding the current state of the discourse explains both the perceived absence of a regional international society in the Middle East and further supports an alternative analysis through the ES. The question of whether or not there is in fact a regional international society remains both contentious and problematic. Firstly, because this depends how we interpret the constitution of the social structure of international societies. This question particularly engages with Hedley Bull's notion of 'revolt against the West' to unpack the relations between regional and international societies (1984a). The second part focuses on the expansion of international society, explaining why the Ottoman Empire is identified as transmitter between Europe and the Middle East. It then shows how the definition of the Middle East is constructed as an 'imagined geography', establishing an analytical link between Said's critique of Orientalism and the ES perspective. The third part explores the 'institutional distinctiveness' of the Middle East in order to assess whether or not there is a 'regional interstate society'. Here I focus on primarily on the state, sovereignty and nationalism, supported by secondary institutions, and a common culture and civilizational identity; all are crucial social forces that mutually constitute the structure of a 'regional interstate society'.

\section{Eurocentrism IR and the study of the Middle East}

Since Samir Amin proposed a systemic critique of 'ideological deformations' of world history that views European culture and modernity as pre-eminent, Eurocentrism has become a radical mode of thought (Amin [1988] 2011, 9). A Eurocentric view of world puts the dominant West at the centre and, therefore, tacitly relegates 'the rest of the world to subordinate positions' (Göl 2014, 34). It seems that 'Eurocentrism is expressed in practically all areas of social thought' (Amin [1988] 2011, 255). As Wallerstein further argues (1997, 94), Eurocentrism is 'a hydra-headed monster and has many avatars' that has expressed itself in social science in the following ways: '1) its historiography, 2) the parochiality of its universalism, 3) its assumptions about (Western) civilisation, 4) its Orientalism, and 5) its attempts to impose the theory of progress'. In a similar manner, IR has also been Eurocentric throughout its disciplinary history, including the ES (though the latter with some important qualifications). In the case of the Middle East, it is crucial to separate Eurocentrism from Orientalism.

\section{The critique of Orientalism and Middle Eastern 'exceptionalism'}

While Eurocentrism in IR legitimates the images and dominant power position of Europe as rational, secular, sovereign states and democratic societies, Orientalism has specific 
implications for the study of the Middle East. H. A. R. Gibb is one of the leading figures in 'modern Anglo-American Islamic studies, who preferred to call himself an Orientalist rather than an Arabist'. Gibb could use 'the ugly neologism "area study" for Orientalism as a way of showing that area studies and Orientalism after all were interchangeable geographical titles' (Said [1978] 1993, 53). Although Said does not emphasize it, the term 'Arabist' has also produced negative connotations: it generates an image of a politically unified community based on Arab culture and identity, which arguably interpreted Arabs within a single social structure centred around an indivisible monolithic Islam that is still considered a reality. Moreover, this doctrine has consistently ignored the non-Arab civilizations (Persian and Turkish) within its construct of the region. It is rather disheartening to see that some still believe a vision of a monolithic Islam, shaped by only Arab culture, and without noticeable consideration of Turkey or Iran. Any astute scholar of Middle Eastern studies knows that there is no single Islam. In fact, 'Islam has become nationalized, producing as many Islams as there are countries with Muslim majorities' even among Arab states and societies (Piscatori 1984, 313). Nevertheless, the general attitude towards downgrading area and regional studies in the hierarchy of disciplines 'ingenuously belies a much more interesting relationship between knowledge and geography', which is particularly relevant to the study of the Middle East in IR (Said [1978] 1993, 53). During the past few decades, there have been new attempts to include 'regional transformation' in international relations theory, but their concern is still how IR theories can be applied 'rather than try to understand other regions' (Paul 2012; Hurrell 2007, 133). Hence, the Anglo-American theories of IR should suffice to be applied to different regional contexts despite their socio-economic, political and cultural differences.

For example, in the case of the ES, the European International Society (EIS) of states became global with universal membership by expanding to other parts of the world (Zhang 2015, 360). Furthermore, the gradual transformation of EIS into a global one led to the uneven development of international society, within which some parts of 'the contemporary global system have more developed international societies than others' by highlighting regional differences (Pourchot and Stivachtis 2014, 71-2). While there is 'nothing in English School's classical literature stands against a regional approach to international society', its implicit emphasis on excessive universalism has prevented it from engaging in the complexity of regional and local histories (Buzan and Zhang 2014). Within ES application to the Middle East, this lack of engagement with local/regional histories is intertwined with Orientalist views of Islam. These views do not delve into the questions of how local culture and social conditions adapt, change or resist once they interact with European institutions, norms and values. They implicitly overlook the existence of local agency during the expansion of the EIS, as evident in OttomanEuropean affairs.

From a historical perspective, 'the expansion of international society' is seen 'as a process, coinciding more or less with the spread of European diplomatic, political and legal norms across the world through modern times, and culminating, to a certain degree itself, in global acceptance of such norms' (Halliday 2009, 3). Moreover, ES 'scholars have tended to see the expansion of society as a progressive development, [and] they have not adequately investigated the role of imperialism in this process' (Suzuki 2009, 17). The acceptance of European norms was not always voluntary, but sometimes indirectly coercive and a subjugating process. The result was contentious for non-European entities - i.e. the Ottoman Empire, Japan and China in the late nineteenth century. When these non-Western empires encountered the EIS, they were implicitly subjugated to the civilizational and normative power of a society of states. Something altogether different than the European example in 
their cultural and civilizational contexts, and therefore, disqualified as alien and inadequate. As a result of subjugating processes, they had to adjust their differences to European modernity and an assumed cultural homogeneity. This can also be interpreted as an early manifestation of 'cultural imperialism' (Tomlinson 1991) that neither IR nor the ES scholars have paid attention to until very recently (see Hobson 2004; Keene 2002). In other words, the classical expansion story does not pay sufficient attention to the question of local agency at the regional level in terms of adaptation, contestation and localization of norms and institutions of Western-global international society (Zhang 2015, 361).

Most ES scholars agree that the institutions of international society had their origins within the European civilization, but some disagree that their expansions to the nonWestern worlds created a multicultural global society (Linklater and Suganami 2006, 74-5). Among later scholars of the ES, there has been not only a growing awareness of the Eurocentric nature of the expansion of international society but also a search for its universal and global character from a critical perspective. Bull and Watson previously argued that the EIS of the nineteenth century had cultural homogeneity, while the global international society of the late twentieth century became culturally heterogonous. However, for the contemporary ES scholar, a culturally heterogeneous and global society can no longer be defined by only its homogenous European civilizational origin and common identity.

Among the ES scholars, Hedley Bull must be credited for particularly engaging with the 'revolt against the West', highlighting the contradictions in a wider pre-9/11 political conjuncture. Bull argues that Western dominance was not without its challengers, which initiated revolt and resistance against Western civilizations' values and institutions. While Bull acknowledged how the historical processes of European expansion, with its implications for power and hegemony encountered non-European civilizations, he also questioned why this expansion encountered the process of resistance. Yet, he failed to engage with the idea of accommodation and adaptation of civilizations and cultures at local and regional levels. The Ottoman Empire's encounter with expanding EIS is important to assess how Western values and institutions were adapted, accommodated, changed or resisted in a Muslim context. This requires a critical interrogation of the complex interplay between global and regional international societies and a revision of the expansion of international society thesis: 'instead of presuming five or so separate regional international societies in the early modern period as stated by, for instance Bull and Watson, one needs to be more cautious and acknowledge the already existing bonds between the regional societies of Europe, the Middle East, India and China in the Old World' (Yurdusev 2009, 91; Göl 2014, 51).

\section{The added value of the ES: 'revolt against the West'}

From a historical perspective, Hedley Bull's critique of the expansion of international society is linked to the dominance of European, and more correctly Western powers after the Second World War. As introduced with reference to the Ottomans, Japan and China, these non-Western political communities were admitted to the EIS on the condition of meeting the criteria for membership laid down by the founding members of a so-called 'universal' international society. One can easily assume, as Bull does, that the European/ Western powers claimed their power and influence over the others not only in economic, military, cultural and intellectual terms but also in the rules and institutions of international society. Therefore, the revolt against the West had its origins in the nineteenth century and became powerful enough to challenge the system in the twentieth century 
(Bull 1984a, 217). Within Bull's classification of the revolt against Western dominance, there were 'five phases or themes' that implicitly recognize the role of local agency and history.

The first revolt was shaped by the struggle for equal sovereignty, which implied the rights of states to sovereign equality irrespective of their European or Christian characters. The second revolt was determined by the struggle for anti-colonialism as part of Asian, African, Caribbean and Pacific peoples for formal political independence of Western European and American - colonial rule. Third was the 'struggle for racial equality or more accurately the struggle of non-white states and peoples against white supremacism'. The fourth revolt was the struggle for economic justice, and finally, the struggle for 'cultural liberation' (Bull and Watson 1984, 220-222).

There are three important implications of Bull's arguments: first, the ES has had a tradition of engaging with non-European struggles and the rise of local agency much earlier than the orthodox IR theories. The ES approach, involving a detailed historical and sociological perspective on the expansion of international society, allows for a questioning of Western dominance and values. For Bull, the rise of Islamic, Hindu and Sikh fundamentalisms demonstrated the reassertion of the traditional and indigenous cultural rights of non-Western peoples that 'has raised the question whether what has been widely interpreted as a revolt against Western dominance carried out in the name of Western values, is not a revolt against Western values as such' (Bull and Watson 1984, 223). In effect, the expansion of international society and revolt against the West draw the ES scholars' attention to new and important issues.

From both historical and analytical perspectives, "there is no one "Western" system or legacy' (Halliday 2009, 12). If Western values, norms and institutions are diverse and contradictory, the revolt and resistance against them must be questioned on the basis of being both diverse and contradictory too. Specifically, resistance and revolutions in the Middle East - Palestine since the 1960s, the Iranian Revolution in 1979, Iraq after 2003, Libya and Syria since 2011 and the rise of the Islamic State in Syria and al-Sham (ISIS) in 2014 - all are dominantly perceived as the rejection of regional arrangements facilitated by the West. While the historical and modern international relations of the Middle East have no shortage of resistance movements, their internal grievances and controversies need to be contextualized with reference to a 'revolt against the imposition of external powers' (Halliday 2009, 18). Neither the legacy of European colonialism in the nineteenth and the twentieth centuries, nor the rise American hegemony and resistance in the twentyfirst century should be left out from any analysis (Krishna 2009). For the same reason, neither should be held solely responsible for all problems and controversies in the Middle East, at least not without analysing the domestic conditions of each state that gave rise to authoritarian regimes.

Second, as Bull himself summarizes succinctly, revolt against the West was not about the rejection of Western values. It was against Western dominance, which indicated the struggles of non-Western states, nations, races, peoples and cultures for equal rights such as sovereignty, self-determination, equality, economic justice and cultural autonomy. 'These rights are today clearly spelt out in conventions having the force of law, even though in many cases they are not enjoyed in practice and no consensus exists about their meaning and interpretation' (Bull and Watson 1984, 227). National liberation and decolonization movements highlighted the variety of political, social and cultural differences in the non-Western worlds as the history of the twentieth century progressed. Among Asian, African and other nonWestern peoples, the Muslim majority societies have attracted special attention due to the rise of so-called 'Islamic terrorism' that unfolded after the 9/11 attacks, which has raised a similar 
question to which Bull was quoted earlier: is Islamic fundamentalism's 'revolt against the West' in fact against Western values? Or, is this a new wave of struggle against the Western dominance as presented in the form of US hegemony? Bull concludes that 'as Asian, African and other non-Western peoples have become stronger relative to the Western powers, they have become freer to adopt a different rhetoric that sets Western values aside, or at all events place different interpretation upon them' (Bull and Watson 1984, 224). While this development is someone evident, Bull however fails to account for the imperialist nature of international society that persistently produce new hegemons that harvest violence and subjugation (Halliday 2009, 18).

Third, the expansion of international society and revolt against the West needs to be more accurately analysed as resulting from competing state interests, rather than cultural differences between the West and Islam, as infamously claimed by Huntington's 'clash of civilisations' thesis (Huntington 1993). In the post-9/11 era, it has become clear that the West can no longer sustain its supremacy over other non-Western peoples and cultures. In the case of the Middle East, there is enough evidence of the imposition of values - i.e. modernization and liberal democracy promotion - by the more powerful on less powerful states. The rise of nationalism, revolution, opposition and resistance can be interpreted as the new forms of counter-hegemonic ideas and practices to proclaim indigenous entitlement: Arab, Palestinian, Kurdish and Turkish nationalists all have used the core ideas of liberation and self-determination created by Western discourses and practices to demand sovereignty and justice (Halliday 2009, 21). As Bull rightly predicted, 'revolt against the West' has not been necessarily a 'revolt against Western values as such'. But is this also a valid argument in the case of Muslim societies in the post-9/11 period? The crux of this debate is to what extent a 'regional interstate society' in the Middle East can evolve? Does it evolve in opposition to a global one dominated by the West? Or, do the regional and the global evolve together and mutually? Do the imposition of Western norms, values and institutions by the hegemonic global power - the US - negate the emergence of a regional international society in the Middle East? In search of answers to these questions, the ES approach is applied to the Middle East in the next section.

\section{The English School and the Middle East as an 'imagined geography'}

The ES can contribute to Middle Eastern studies from three perspectives: analytical, historical and definitional (Buzan and Gonzales-Pelaez 2009, 243). From a historical perspective, the expansion of international society to include the Ottoman Empire offers three analytical insights to explain the European relations with the Middle East as an 'imagined geography': first, the Ottoman Empire, due to its different culture and religion - Islam - was the first 'other' of EIS; second, the increasingly 'modernized' Ottoman Empire in the late nineteenth century 'performed a kind of transmitter role in the Middle East'; third, the formation of the modern Middle East cannot be explained without the complex interaction between the Islamic Ottoman Empire and the expansion of EIS (Yurdusev 2009, 79). The emphasis on the changing role of the Ottoman Empire from being an 'other', to a 'transmitter' between Europe and the Middle East, is a departure point to understand the nature of relations between regional and international societies.

\section{The Ottoman Empire as transmitter between Europe and the Middle East}

The long history of Ottoman-European relations reflects a double-edged legacy on the emergence of a regional international society in the Middle East. As highlighted earlier, whether or not there is a regional international society in the Middle East is contentious 
because it is relative to what constitutes the social structure of international societies. In the classic ES conceptualization, it is argued that 'the tributary system is also an articulation of the historical existence of international society in East Asia with its own social structure and a particular set of institutions that help define norms of acceptable and legitimate state behaviour' (Zhang 2015, 362). Historically, some of the key European institutions that constitute an international society, such as diplomacy, international law, a capitalist market, nationalism and war, can be traced back within the Middle East.

There is historical evidence that 'the Ottoman Empire was integrated through the operation of a redistribute-tributary network' and was an integral part of the world economy (Kasaba 1988, 3). From this perspective, the Ottoman tributary system indicates a historically embedded social structure in the Middle East that constitutes an international society with its particular set of institutions. The Ottoman system also demonstrated the functioning of diplomacy, nationalism and war prior to its incorporation into world capitalist economy and European international law in the nineteenth century (Adanir 2005). There is a strong case for calling the Middle East a regional international society due to 'institutional distinctiveness' as defined by its primary institutions - state, nationalism and sovereignty - and secondary institutions - common culture and identity-based regional organizations (Buzan and Gonzalez-Pelaez 2009), as will be identified later.

Among the mainstream IR theories, ES scholars offer critical readings of European history, proposing that 'the Ottoman Turkish Empire that survived into the twentieth century' had the most remarkable impact on the 'European system and the evolution of international society' (Watson 1992, 116). In its earliest years, the Ottoman Empire played a decisive role in two important movements in Europe, 'the Protestant Reformation and the Catholic Counter-Reformation, which together with the Renaissance, transformed European society and led ultimately to the creation of an international society in Europe's image' (Naff 1984,145). In particular, the image of rational, secular and sovereign states in Europe disqualified the Ottoman system as alien and inadequate. As Neumann and Welsh (1991) argued, the Islamic Ottoman Empire remained the 'other' in the definition of European identity. The 'otherness' of the Ottomans was shaped by its religious identity and culture as opposed to Christianity. Both Bull and Watson emphasized that the militarily powerful Ottoman Empire was not only the historic enemy of Christendom but also a non-European entity, due to its different culture, religion and race that contributed towards constructing a European 'we' and a 'universal international society' (Bull and Watson 1984, 427; Bull 1984b, 117). The Sublime Porte - Bab-I Ali - was a major actor in the European states system, but never part of the EIS (Göl 2014, 34). The Islamic identity of the Ottoman Empire was not confined to cultural and societal spheres, but seen as an essential part of state relations as claimed by the early scholars of ES.

For the early ES, however, the 'Ottoman theories of state and government [are] derived from the Muslim concept that God is the source of all authority and law, that government exists to enable the community of believers [Muslim umma] to fulfill its obligation to God. The community, and the state, constitutes the basic Muslim polity, transcending all boundaries' (Naff 1984, 143). Similarly, Naff's contemporaries Buzan and Little argue that the 'contradiction between religion and politics in the Islamic world blocked its path to modernization; while it was socially cohesive it was politically incoherent, lacking both boundaries and well-rooted states' (2000, 320-21). These negative interpretations of the relationship between Islam and state are, in fact, somewhat 'arbitrary' views of 'modernization' and 'states', in the sense that Said developed in 
Orientalism (Said [1978] 1993). What accepted as a modern and European state has established certain standards as international and universal practice. While there may be 'such things as positive history and geography which in Europe and the US have impressive achievement to point to' (Said [1978] 1993, 55), the Islamic world has never been regarded as part of this progressive story. Despite the golden age of the Muslim world in astronomy, medicine and mathematics, Islamic knowledge has hardly ever been regarded as having reached the same level of European science and rationality. The different paths to progress in Muslim societies have been disqualified, rendered as outside of the European model.

Among Orientalist scholars, H. A. Gibbon was the first Western scholar to engage with the origins of state in the Middle East. Following him, other scholars such as Houtsma, Huart, Marquart, Massignon and Mordtmann all emphasized "the "oriental" nature of the Ottomans and accepted the essentially Turco-Muslim identity of the founders of the state' (Kafadar 1995, 32-5). However, as the contemporary studies of Ottoman history argue, 'the rise of the Ottoman state had to be studied against the background of centuries of warfare, cultural transformation, acculturation, and the settlement of Muslims and Turks in medieval Anatolia' (Kafadar 1995, 36-7). In the case of the Ottomans, the state was not established simply on the principle of Islam and the Shari'a (Islamic Law), but on the legacies of political institutions of earlier empires - Roman, Byzantium, Persian - that ruled between Europe and Asia Minor. The Ottomans produced a synthesis of Western political reason and Eastern philosophical views of the purpose of state, within which Islam was protected and promoted, largely by the existence of a strong empire. For the Ottoman historian Mustafa Naima (1655-1716), who wrote The Annals of the Empire between 1591-1659 of the Christian Era, argued that the main purpose of the state was '(1) to organize the exploitation of the wealth belonging to the ruler, (2) provide for the expansion and defence of this wealth, (3) keep order, and (4) promote Islam, while permitting the practice of other religions with the ruler's dominions' (Shaw 1976, 112), objectives shared by Europe's developing states.

The evolution of the Ottoman state from a small principality in Anatolia to an Islamic imperial power stretching to three continents for 600 years proves the complexity of its socio-economic, political and military structures. By reducing the structure of the Ottoman state to Islam, one cannot explain why an 'Oriental' empire maintained its internal cohesion over heterogeneous religious and cultural groups - i.e. Muslim and non-Muslim millets - with such historical resilience. This probably explains why the Sublime Porte was the first and only Islamic entity to be 'admitted' to EIS in midnineteenth century (Bull and Watson 1984, 427). Neither its specific geo-cultural existence in between Europe and Asia nor the geopolitical legacies of Byzantium and Persian Empires in this geographical space should be ignored. As the transformation of the Islamic Ottoman Empire into a modern Turkish nation state at the beginning of the twentieth century demonstrates, Islam has been nationalized and differentiated from its multifaceted Arab successors. The historical legacy of the state as an institution in the Turkish context proves that contemporary challenges that Arab societies are facing today cannot be simply reduced to Islam's rejection of the state as a Western concept in the modern Middle East. The correlations between Orientalist views of Islam and the so-called rejection of the Western model of the state can be analysed through the construction of the Middle East as 'imagined geography', which I turn to next. 


\section{Defining the Middle East}

The Middle East is an 'imagined geography' that has no meaning unless one locates it inbetween the West and the East. Defining the Middle East as 'middle' was a reflection of the mid-nineteenth-century British colonial strategies that imagined the East as middle, near and far (Hanafi 1998, 1-9). Alfred Mahan first coined the term in 1902, 'to define the maritime and adjacent land area between European and British India' (Adelson 1994, 22; Halliday 2009, 14). By analogy with Alfred Mahan's use of the great landmasses of the world in particular on the Central Asian 'heartland' and the Far East, the Middle East referred to the land between Arabia and India as 'imaginary geography'.

As Davison has argued, 'the fact remains that no one knows where the Middle East is, although many claim to know' $(1960,1)$. Given the fact the Ottoman Empire was the representative of Muslims in the East, the 'middle' east was a meaningless term from the position of the Sublime Porte. Between the sixteenth and nineteenth centuries, the Arab land of the Empire was divided into different sanjacks (districts) and eyalets (provinces), which were replaced by vilayets (wilayah in Arabic - provinces) in 1867 and the number of vilayets kept changing depending on the annexation of territories (Yurdusev 2009, 82). In 1876, the first Ottoman Constitution - Kanun-i Esasi - (article 1) defined the Empire as a 'territorial unit' in the European sense. Therefore, the Ottoman state structure was familiar with the principle of 'territoriality', which found its way into the late Ottoman vilayet organization of the Middle East. The Arab land under the Ottoman rule was divided into nine major vilayets in 1905: Hedjaz, Yemen, Basra, Baghdad, Mosul, Haleb, Souriya (Syria), Beyrout (Beirut) and Tripoli (Heidborn 1908, 7-8).

In the twentieth century, the 'Middle East' was imagined as an integral part of Eurocentric and Orientalist worldviews. The images and (mis)representations of the 'East', 'Orient' or 'Islamic world' not only characterized the Middle East, which is consigned to the category of 'non-Western' or 'the rest of the world' but also imagined a region "peopled by "Others" that can be labeled as "uncivilized", "traditional", "irrational", and "violent", much as they were centuries ago' (Said [1978] 1993, 1997; Göl 2010, 2). Consequently, the Middle East remains to be a 'traditional', 'uncivilized', 'violent' and 'unique' region in Western minds. These images have contributed towards producing its regional 'exceptionalism'.

When compared to other regions, the Middle East is often seen as 'unique', 'based on the implicit assumption that Islam - [despite] all its complexities, contradictions, and cultural differences, as well as different political trajectories - is monolithic and homogenous, and that Islam is the primary referent' in politics (Göl 2010, 3). Hence, a homogenous Islam is incompatible with the idea of sovereign states and nationalism based on a division among ethnic groups. It is Islam that makes the Middle East 'unique' in Western minds. But like other postcolonial regions, there is nothing 'unique' about the Middle East, for the following reasons: first, the arbitrary imposition of boundaries by colonial structures has never reflected the complexity of identities at ethnic, tribal and national levels. Second, the lack of an organic relationship between 'citizens' and the state has weakened the loyalties of certain minorities and marginalized groups, and has remained continuously present in Middle East states. Third, the loose relations between states and societies have persistently sustained sub- and/or supra-state identities and loyalties that fostered irredentist movements in modern politics.

The construction of the Middle East as an 'imagined geography' by European colonial powers shows how the expansion of imperialism and the EIS not only gave the Middle East its modern name but also its key institutions, the state and the ideology of nationalism. There 
is a case for the argument that a 'regional interstate society' exists in the Middle East despite its 'institutional distinctiveness' (Buzan 2004, 161-204; Buzan and Gonzalez-Pelaez 2009, 241). While accepting the existence of differences between regional and international societies, ES scholars need to be 'more aware of the distinction between the Western core of international society and its global projection, and what is actually happening in the periphery' (Buzan and Gonzalez-Pelaez 2009, 240), as is the case within the Middle East.

\section{International Society and the 'institutional distinctiveness' of the Middle East}

A better understanding of the 'interplay between regional and global levels' is immanent for two reasons: on the one hand, '[i]nternational society at the global level is almost inevitably thin, but as most strongly shown by the EU, regional developments may well be thicker'. On the other hand, the 'regional manifestations of international social structure' can no longer be 'marginalized and resisted' (Buzan and Gonzalez-Pelaez 2009, 30). However, emphasizing the example of the EU as a successful regional international society reaffirms Eurocentric assumptions unless it is tested in geographies outside European zone. The Middle East as a regional context offers both opportunities and challenges to this aim by questioning key institutions of international societies.

(a) The primary institutions of the Middle Eastern 'regional interstate society': state, nationalism and sovereignty, which are compared and contrasted to the primary institution at the global level - state sovereignty, diplomacy, territoriality, great power management, war, nationalism, equality of people, the market and environmental stewardship (Gonzalez-Pelaez 2009, 94-115).

(b) The secondary institutions of the Middle Eastern 'regional interstate society', which stem from the imperative generated by particular above-mentioned primary institutions: the Arab League, the Gulf Cooperation Council (GCC), the Arab Cooperation Council (ACC), the Arab Maghreb Union (AMU), the Organisation of Arab Petroleum Exporting Countries (OAPEC) and the Organisation of the Islamic Conference (OIC) (Murden 2009, 125-130).

In fact, even before the expansion of the European model, the state as an institution has dominated the history of the Middle East, and therefore requires a more historically nuanced interpretation than the essentialist views of Islam and the state.

\section{The state and nationalism}

According to Adda Bozeman, the sovereign state as the core concept of the international system is 'critically embattled everywhere'; however, most notably within the Middle East and Africa (1984, 405). In the case of the Muslim societies, it is commonly assumed that the rejection of the state has resulted in an attempt to 'reject the western concept of a community of states in favour of traditional Islamic concepts', as described in the Expansion of International Society (Bozeman 1984, 405; Bull and Watson 1984). However, as discussed with reference to the Ottoman Empire, the Turks adapted and accommodated to the requirements of EIS differently than other Muslim societies. There is no monolithic Islam that rejects the modern concept of state, but different political trajectories of the state within various Arab, Persian and Turkish paths.

Within the modern Middle East, there were four key processes which shaped contemporary politics: first, the process of state formation as administrative and coercive 
political actor; second, the creation of national identities; third, secularization; and fourth, growing resistance to the colonial external and regional powers, in the form of ethnonationalist and Islamic movements (Halliday 2005, 86-9). The process of state formation followed a different path in the Arab world after the end of British and French colonialism. First, Arab peoples and states gained independence at different stages of decolonization in the Middle East (Bahrain in 1971, Iraq in 1958, Jordan 1946, Kuwait in 1961, Lebanon in 1943, Oman and Qatar in 1971, Palestine in 1988, Saudi Arabia in 1932, Syria in 1946, United Arab Emirates in 1971 and Yemen - South Yemen in 1967 and the unification in 1990). Second, while the state has faced challenges in the form of panArabism and pan-Islamism, it still remains the main actor in the Middle East. The uneven development of the 'nation', the 'state' and the 'nation state' does not mean that these are artificial constructs are incompatible with the Middle East. The division of humanity into nation states was not a natural process in Europe either. Historically, in the newly defined modern Middle East there are some states, i.e. Iran, Yemen and Morocco, that could be traced back within the pre-Ottoman and precolonial period. An accurate and sensitive reading of the state in Middle Eastern history should combine the expansion of European colonialism and the rise of nationalism as an ideology.

Like many other postcolonial regions, nationalism has manifested itself in two major forms in the Middle East: first, the nationalism of particular ethnic groups and individual states (including Arabs and non-Arabs); second, the cultural form of the Arab nationalism that transcends individual state identities to claim a collective identity and regional unity i.e. pan-Arabism. First, the idea of Arab nationalism needs to be understood from a historical perspective, within which one can identify a dual function: on the one hand, the Arabs were united under the ideology of Arab nationalism against the first colonial power in the region - the Ottoman Empire - and independence prevailed in the form of the Arab Revolt against the Turkish yoke. On the other hand, the idea of Arab nationalism turned itself into the movements of self-determination after the disintegration of the Ottoman Empire. As Hourani argues, the widespread form of nationalism was territorial in the Middle East between the two World Wars, and only later became predominantly ethnic $(1981,86)$. Second, pan-Arabism was an important force of resistance during the anti-colonial movements in the 1950s and 1960s. There is no doubt that 'pan-Arabism, by its nature, aspired to the utmost Arab unity, threatening the sovereignty of the new fragile borders' (Gonzalez-Pelaez 2009, 94). But in contrast, pan-Arabism strengthened the principle of sovereignty because gaining independence from colonial powers was a necessary step towards statehood, after which Arab unification would have followed. The pan-Arab ideal has never been achieved, but the principle of sovereignty secured its place in the region after pan-Arabism. When 'the Charter of the League of Arab states prioritized the respect for sovereignty' in 1945, it was institutionalized as much as with regard to their European counterparts in international society (Gonzalez-Pelaez 2009, 94). In the post-Second World War history of the Middle East, the creation of Israel as a Jewish state at the expense of indigenous Arabs - Palestinians - gave a new meaning to the rise of Arab nationalism and pan-Arabism under Nasser's leadership.

It is evident that nationalism has functioned during the process of state formation and identity construction in the Middle East in comparable way to other regions. For the critics of Islam, there can be no separation between religion and nationalism in Muslim societies. In this context, one can argue that 'Islamist nationalism' is the third form of nationalism within the Middle East (Yurdusev 2009, 87). In particular, Islam does not accept ethnic divisions, and therefore acts as nationalism because of the unitary nature of the Muslim community (umma) (Göl 2005, 115). The centuries-old national aspirations of two 
indigenous stateless ethnic groups in the Middle East are two strong examples which prove these claims wrong: the continuous national struggles of Palestinians and Kurds demonstrate that modern nationalism is persistent in the Middle East. The ideology of pan-Islamism has been a historically strong advocate of a unitary Muslim community, supporting the claims regarding 'Islamist nationalism'. However, in addition to separate nationalisms, the rise of pan-Arabism as opposed to pan-Islamism suggests that we should rethink the true nature of 'Islamist nationalism'. More importantly, the clash of pan versus individual state identities and loyalties further questions the role of identity in the Middle East.

Turkish, Iranian and Arab states have been organized around the principles of sovereignty, nationality and territoriality that have survived through to the twenty-first century. Pan-ideologies - pan-Ottomanism, pan-Turkism and pan-Islamism - were historically tested and failed to unite the Muslim peoples of the East at the end of the First World War (Göl 2013, 61-3). In the twentieth century, 'two transnational ideas - panArabism and pan-Islamism - continued to cast a shadow over the region, but they could not stop the territorial state consolidating its own reality' (Murden 2009,137). The challenges stemming from pan-ideologies to Western values and institutions have not succeeded as of yet. In this context, the institutions of the state, sovereignty and nationalism not only constitute the social structure of Middle Eastern order but also relate to the common culture and identity as part of above-mentioned secondary institutions.

\section{Common culture and identity}

As highlighted by Buzan and Gonzalez-Pelaez (2009), the 'secondary institutions' of the Middle Eastern interstate society indicate the existence of a common culture and identity. Does having a civilizational identity (which was seen as an important requirement for EIS) around Arab culture support the case for the Middle East as a 'regional interstate society'? It is true that none of the Arab-centred organizations - the Arab League, ACC, AMU and OAPEC - has been as effective as the EU, and most are frequently regarded as dysfunctional, ineffective and 'dead letters' that never rise beyond the rhetorical level. While they underline the existence of a shared Arab identity and common culture, what does the failure of these trans-state organizations indicate? Has the unity of Islam been more powerful than the common culture of Arabs?

The pan-Islamic utopia has never withered away in the Middle East since its inception in the late nineteenth century. Pan-Islam is seen as a mechanism for creating an international society of Muslims (umma). In the twentieth century, it was the Iranian Revolution of 1979 that introduced Islam as a revolutionary force. Since then and the emergence of what some call the 'global jihadi network', a popular view has developed that Islam is irreconcilably opposed to an international society built on the peaceful coexistence and cooperation of sovereign states (Hashmi 2009, 200). Because of Islam's assumed incompatibility with Western values, it is often supposed that an international society of Muslims will conflict with a universal international society, and one that would threaten the development of an Islamic subsystem. As highlighted earlier, these claims are based on the essentialist views of a monolithic Islam, which does not reflect the realities of various Muslim societies. As students of Middle Eastern politics know, there is enough historical evidence that 'pan-Islam has proven no more effective than pan-Arabism in mobilizing elites and masses to create alternative to the nation state' (Hashmi 2009, 199). In particular, the OIC can be seen as the formal embodiment of pan-Islam at the interstate level today. However, the 'OIC's commitment to the principles of the UN Charter and 
international law found in its first charter and reaffirmed in its second is more than mere rhetoric' (Hashmi 2009, 200). Despite the promises of pan-Islam, the OIC has never reached the success of the EU as an effective organization but it still functions as a secondary institution to promote the development of an international society of Muslims.

In the twenty-first century, the notion of pan-Islam gained a controversial meaning when the ISIS claimed the establishment of a transnational 'Islamic State' - the Caliphate - by replacing existing boundaries between various states in the Middle East. Contrary to popular perception in Western societies, nobody knows what an Islamic State is. There are already two competing models: the Islamic Republic of Iran and the Kingdom of Saudi Arabia. Despite their claims, the nation state based on the European model 'has still proven remarkably adaptable and resilient. Unable to achieve a clear idea of what constitutes an Islamic alternative to the nation-state or how to bring it about, advocates of pan-Islam seem by and large reconciled for the time being to symbolic, pluralist manifestations' (Hashmi 2009, 200). They continue to do so as long as the causes of 'revolt against the West' are sustained in the region. The idea of an Islamic State will remain to be an alternative lure if current conflicts and grievances continue weakening the coercive machinery of modern states, and therefore intensifying the existing political vacuum in the Middle East.

The failure of Arab trans-state organizations can be explained by two related regional and international conditions: first, the Middle East system is based on a 'fragmented core' consisted of Arab states and a 'periphery of more or less hostile stronger and more modern non-Arab states (Iran, Turkey and Israel)' (Hinnebush 2009, 204). However, both Arab and non-Arab states are tied together by conflicts and competitions within a 'regional security complex' that constitute 'the thinnest' of regional international societies (Buzan and Wæver 2003, 189; Hinnebush 2009, 204). Second, the 'fragmented core' has been further weakened by the lack of a 'regional hegemon' that led to regional rivalries among Arab states - Egypt, Iraq and Saudi Arabia and their non-Arab challengers, Iran and Turkey. The causes of the Iran-Iraq war in the 1980s and the Gulf Wars in the 1990s are better explained within this context. Similarly, the unfolding events and conflicts in the post-Saddam, post-Qaddafi and post-Mubarak era indicate not only the rise of an anarchical regional society but also the continued and somewhat intensified search for a hegemon. Unlike other regions organized around a powerful centre - i.e. China-centred East Asia or Japan-centred Asia - there is neither an Egypt-centred nor an Iran- or Turkeycentred Middle East. The lack of a regional hegemon has produced a power vacuum that has been manipulated by the rise of violent resistance movements and terrorist organizations - i.e. Al-Qaida and the ISIS - in current affairs.

\section{Concluding remarks}

This article contributes towards a growing critique of Eurocentrism in IR by challenging the 'exceptionalism' of the Middle East, where the lack of regional international society is assumed. The main argument of this article is that the Middle East is in fact a 'regional interstate society'. It locates the Middle East without losing its 'institutional distinctiveness' within the studies of IR and ES on three dimensions. First, the historical analysis of Ottoman-European relations demonstrates how the state system with its key institutions evolved in the Middle East. Second, the resilience of the state, sovereignty and nationalism in the region disprove Islam's assumed incompatibility with modern state and global international society. Third, international societies are bound together by culturally and historically contingent values that define the civilizational identities reciprocally. In the 
Middle Eastern context, the ideas of pan-Arabism and pan-Islamism, despite their failure, have strongly supported the existence of a common culture and civilizational identity as one of the main requirements of a regional international society.

The added value of this article's general findings is as follows: first, the 'exceptionalism' of the Middle East that prevents the emergence of a regional international society is historically questioned. The classical expansion story of EIS pays insufficient attention to the existence of local agency, even when accounting for Bull's notion of the 'revolt against the West' in terms of adaptation, accommodation and resistance to norms and institutions of global international society. Second, when it comes to understanding the relationship between the Middle Eastern regional and Western-global international societies, it is unlikely to find any regional differentiation at all other than arising from resistance against the legitimacy of external intrusions. Third, the recognition of an uneven progress of regional international societies does not mean that a global international society does not exist. On the contrary, it shows that the two mutually evolve as part of accommodation and resistance that offers a thicker analysis of world affairs. Finally, the Middle East will continue to be a litmus test of whether or not a truly global international society is possible. Within the regionally uneven and globally combined development, the Middle East is inextricably connected to Western-global international society and continues to challenge how the global society should allow the regional society to develop despite its civilizational differences.

\section{References}

Adanir, F. 2005. "Turkey's Entry into the Concert of Europe." European Review 13 (3): 395-417. doi:10.1017/S1062798705000530.

Adelson, R. 1994. London and the Invention of the Middle East: Money, Power and War, 1902-1922. New Haven: Yale University Press.

Amin, S. (1988) 2011. Eurocentrism: Modernity, Religion, and Democracy. New York: Monthly Review Press.

Bozeman, A. 1984. "The International Order in a Multicultural World." In The Expansion of International Society, edited by H. Bull and A. Watson. Oxford: Clarendon Press.

Bull, H. 1984a. "Revolt Against the West.." In The Expansion of International 640 Society, edited by H. Bull and A. Watson. Oxford: Clarendon Press.

Bull, H. 1984b. "The Emergence of a Universal International Society." In The Expansion of International Society, edited by H. Bull and A. Watson. Oxford: Clarendon Press.

Bull, H., and A. Watson, eds. 1984. "Conclusion." In The Expansion of International Society. Oxford: Clarendon Press.

Buzan, B. 2004. From International to World Society: English School Theory and the Social Structure of Globalisation. Cambridge: Cambridge University Press.

Buzan, B., and A. Gonzalez-Pelaez, eds. 2009. International Society and the Middle East: English School Theory at the Regional Level. Basingstoke: Palgrave MacMillan.

Buzan, B., and R. Little. 2000. International Systems in World History: Remaking the Study of International Relations. Oxford: Oxford University Press.

Buzan, B., and O. Wæver. 2003. Regions and Power: The Structure of International Security. Cambridge: Cambridge University Press.

Buzan, B., and J. Zhang. 2014. Contesting International Society in East Asia. Cambridge: Cambridge University Press.

Davison, R. H. 1960. "Where is the Middle East?" Foreign Affairs (July). Accessed 14 September 2014. http://www.foreignaffairs.com/articles/71575/roderic-h-davison/where-is-the-middle-east

Göl, A. 2005. "Imagining the Turkish Nation through 'Othering' Armenians." Nations and Nationalism 11 (1): 121-139. doi:10.1111/j.1354-5078.2005.00195.x.

Göl, A. 2010. "Editor's Introduction: Views from the 'Others' of the War on Terror." Critical Studies on Terrorism 3 (1): 1-5. doi:10.1080/17539151003594160. 
Göl, A. 2013. Turkey Facing East: Islam, Modernity and Foreign Policy. Manchester: Manchester University Press.

Göl, A. 2014. "Europe, Islam and Pax Ottoman, 1453-1774." In International Orders in the Early Modern World: Before the Rise of the West, edited by S. Suzuki, J. Quirk, and Y. Zhang. London: Routledge.

Gonzalez-Pelaez, A. 2009. "The Primary Institutions of the Middle Eastern Regional Interstate Society." In International Society and the Middle East: English School Theory at the Regional Level, edited by B. Buzan and A. Gonzalez-Pelaez. Basingstoke: Palgrave MacMillan.

Halliday, F. 2005. The Middle East in International Relations: Power, Politics and Ideology. Cambridge: Cambridge University Press.

Halliday, F. 2009. "The Middle East and Conceptions of "International Society"." In International Society and the Middle East: English School Theory at the Regional Level, edited by B. Buzan and A. Gonzales-Pelaez. Basingstoke: Palgrave MacMillan.

Hanafi, H. 1998. "The Middle East, in Whose World? The Fourth Nordic Conference on Middle Eastern Studies: The Middle East in Globalizing World," Oslo, August 13-16. Accessed 14 September 2014. http://www.org.uib.no/smi/pao/hanafi.html

Hashmi, S. H. 2009. "Islam, the Middle East and the pan-Islamic Movement." In International Society and the Middle East: English School Theory at the Regional Level, edited by B. Buzan and A. Gonzalez-Pelaez. Basingstoke: Palgrave MacMillan.

Heidborn, A. 1908. Manuel de Droit Public et Admistratif de I'Empire Ottoman [The Manual for Public and Administrative Rights of the Ottoman Empire] Vienna: Leipzig. Accessed 14 September 2014. https://archive.org/details/manueldedroitpu00heidgoog

Hinnebush, R. 2009. "Order and change in the Middle East: A Neo-Gramscian Twist on the International Society Approach." In International Society and the Middle East: English School Theory at the Regional Level, edited by B. Buzan and A. Gonzalez-Pelaez. Basingstoke: Palgrave MacMillan.

Hobson, J. M. 2004. The Eastern Origins of Western Civilisation. Cambridge: Cambridge University Press.

Hourani, A. 1981. The Emergence of the Modern Middle East. Basingstoke: Macmillan Press.

Huntington, S. P. 1993. "The Clash of Civilisations?" Foreign Affairs 72 (3): 22-49.

Hurrell, A. 2007. "One World? Many Worlds? The Place of Regions in the Study of International Society." International Affairs 83 (1): 127-146. doi:10.1111/inta.2007.83.issue-1.

Kafadar, C. 1995. Between Two Worlds: The Construction of the Ottoman State. Berkeley: University of California Press.

Kasaba, R. 1988. The Ottoman Empire and the World Economy: The Nineteenth Century. Albany: SUNY Press.

Keene, E. 2002. Beyond the Anarchical Society: Grotius, Colonialism and Order in World Politics. Cambridge: Cambridge University Press.

Krishna, S. 2009. Globalisation and Postcolonialism: Hegemony and Resistance in the Twenty-first Century. Maryland: Rowman \& Littlefield.

Linklater, A., and H. Suganami. 2006. The English School of International Relations: A Contemporary Reassessment. Cambridge: Cambridge University Press.

Murden, S. W. 2009. "The Secondary Institutions of the Middle Eastern Regional Interstate Society." In International Society and the Middle East: English School Theory at the Regional Level, edited by B. Buzan and A. Gonzalez-Pelaez. Basingstoke: Palgrave MacMillan.

Naff, T. 1984. "The Ottoman Empire and the European States System." In The Expansion of International Society, edited by H. Bull and A. Watson. Oxford: Clarendon Press.

Neumann, I. B., and J. M. Welsh. 1991. "The Other in European Self-Definition: An Addendum to the Literature on International Society." Review of International Studies 17: 327-348.

Paul, T. V., ed. 2012. International Relations Theory and Regional Transformation. Cambridge: Cambridge University Press.

Piscatori, J. 1984. "Islam in the International Order." In The Expansion of International Society, edited by H. Bull and A. Watson. Oxford: Clarendon Press.

Pourchot, G., and Y. A. Stivachtis. 2014. "International Society and Regional Integration in Central Asia." Journal of Eurasian Studies 5 (1): 68-76. doi:10.1016/j.euras.2013.09.001.

Said, E. 1997. Covering Islam: How the Media and the Experts Determine How We See the Rest of the World. London: Vintage. 
Said, E. W. (1978) 1993. Orientalism: Western Conceptions of the Orient. New York: Random House.

Shaw, S. J. 1976. History of the Ottoman Empire and Modern Turkey, Vol. 1, Empire of the Gazis: The Rise and the Decline of the Ottoman Empire, 1280-1808. Cambridge: Cambridge University Press.

Suzuki, S. 2009. Civilization and Empire: China and Japan's Encounter with European International Society. London: Routledge.

Tomlinson, J. 1991. Cultural Imperialism: A Critical Introduction. London: Continuum.

Wallerstein, I. 1997. "Eurocentrism and Its Avatars: The Dilemmas of Social Science." New Left Review I 226: 93-108.

Watson, A. 1992. The Evolution of International Society: A Comparative Historical Analysis. London: Routledge.

Yurdusev, A. N. 2009. "The Middle East Encounter with the Expansion of European International Society." In International Society and the Middle East: English School Theory at the Regional Level, edited by B. Buzan and A. Gonzales-Pelaez. Basingstoke: Palgrave MacMillan.

Zhang, Y. 2015. "Regional International Society in East Asia? A Critical Investigation." Global Discourse 5 (3): 360-373. doi:10.1080/23269995.2015.1053190 